\title{
The 'Latte Revolution'? Regulation, Markets and Consumption in the Global Coffee Chain
}

\author{
STEFANO PONTE * \\ Centre for Development Research, Copenhagen, Denmark
}

\begin{abstract}
Summary. - Coffee is a truly global commodity and a major foreign exchange earner in many developing countries. The global coffee chain has changed dramatically as a result of deregulation, new consumption patterns, and evolving corporate strategies. From a balanced contest between producing and consuming countries within the politics of international coffee agreements, power relations shifted to the advantage of transnational corporations. A relatively stable institutional environment where proportions of generated income were fairly distributed between producing and consuming countries turned into one that is more informal, unstable, and unequal. Through the lenses of global commodity chain analysis, this paper examines how these transformations affect developing countries and what policy instruments are available to address the emerging imbalances. (C) 2002 Elsevier Science Ltd. All rights reserved.
\end{abstract}

Key words - coffee, commodity chains, development, globalization, regulation

\section{INTRODUCTION}

Every day, about 2.25 billion cups of coffee are consumed in the world (Dicum \& Luttinger, 1999 , p. IX). Yet, the act of - and symbols attached to - coffee drinking are not the same as they were 20 years ago. New consumption patterns have emerged with the growing importance of specialty, fair trade, and organic coffees. Coffee bar chains have spread dramatically, although the relative coffee content of the final consumption "experience" in these outlets is extremely low. ${ }^{1}$ Coffee bar chains sell an ambience and a social positioning more than just "good" coffee. In short, the global coffee chain has gone through a "latte revolution," 2 where consumers can choose from (and pay dearly for) hundreds of combinations of coffee variety, origin, brewing and grinding methods, flavoring, packaging, social "content," and ambience. At the same time, international prices for the raw product ("green" coffee) are the lowest in decades. Coffee industries in developing countries are in disarray. Coffee farmers are losing a source of livelihood.

This paper explores this contradiction through the analysis of the changing features of the global coffee-marketing chain. It examines the consequences of the shift that has occurred in the last two decades in the regulatory framework at the international level-with the end of the quota system managed by the In- ternational Coffee Organization (ICO). It also explains how market liberalization and deregulation in producing countries has decreased their capability of controlling exports and building up stocks, therefore weakening their market power. Finally, the paper examines how new consumption patterns and changing strategies by key corporate actors (adoption of supply-managed inventory, consolidation, branding) affect other actors in the chain. These major shifts in international and domestic regulation, consumption, and corporate behavior are assessed in relation to the organizational features of the chain, its mode of governance, the ownership characteristics at various "nodes," and the distribution of income along the coffee chain.

The next section explains the main features of the global commodity chain (GCC) analysis (also known as "value-chain analysis.") Section 3 lays out the fundamental characteristics of the

\footnotetext{
* I would like to thank Henry Bernstein, Niels Fold, Deepa George, Gary Gereffi, Peter Gibbon, Michael Friis Jensen, Poul Ove Pedersen, and two anonymous referees for helpful comments on earlier drafts of this paper. I am also thankful to the Danish Social Science Research Council and the Centre for Development Research, Copenhagen for funding the research project under which this paper was generated. Final revision accepted: 20 February 2002.
} 
global coffee chain. The following section analyses some of the consequences of the switch in coffee trade "regimes" that took place starting in the late 1980s. Section 5 focuses on market power and corporate strategies in the current configuration of the global coffee chain. This is followed by the examination of how coffee consumption is evolving in the industrialized economies (the "latte revolution"). Section 7 assesses the insights offered by the restructuring of the global coffee chain to wider debates in the GCC literature. The final section assesses what the coffee study has to say about the role of commodity trade in development and provides several policy options to address the emerging imbalances in the global coffee chain.

\section{GLOBAL COMMODITY CHAIN ANALYSIS}

The main methodological instruments used in this paper are drawn from GCC analysis. The GCC approach was developed by Gereffi and others within a political economy of development perspective. In this body of work, the international structure of production, trade, and consumption of commodities is disaggregated into stages that are embedded in a network of activities controlled by firms and enterprises. The systematic study of commodity chains seeks to explain the spatial organization of production, trade and consumption of the globalized world economy (Gereffi, Korzeniewicz, \& Korzeniewicz, 1994, p. 2). A commodity chain in this context is seen as "a network of labor and production processes whose result is a finished commodity" (Hopkins \& Wallerstein, 1986, p. 159). Specific processes within a commodity chain are represented as "nodes" linked together in networks. Therefore, we can see a commodity chain as "a set of interorganizational networks clustered around one commodity or product" (Gereffi et al., 1994, p. 3), in which networks are situationally specific, socially constructed, and locally integrated.

Gereffi identifies four dimensions of GCCs: the input-output structure, the geographical coverage, the governance structure (Gereffi, 1994, p. 97), and the institutional framework through which national and international conditions and policies shape the globalization process at each stage in the chain (Gereffi, 1995). The input-output structure and the geographical coverage of GCCs have been used mainly descriptively to outline the configuration of specific chains. The governance structure has so far received the most attention, since this is where the key notions of entry barriers and chain co-ordination appear in the analytical framework, and where the distinction between "producer-driven" and "buyer-driven" GCC governance structures is introduced. Producerdriven chains are usually found in sectors with high technological and capital requirements, where capital and proprietary know-how constitute the main entry barriers (automobiles, aircraft, computers). In these chains, producers tend to keep control of capital-intensive operations and subcontract more labor-intensive functions, often in the form of vertically integrated networks (Gereffi, 1994). Buyer-driven chains are found in generally more laborintensive sectors, where information costs, product design, advertising, and advanced supply management systems set the entry barriers (garments, footwear). In these chains, production functions are usually outsourced and key actors concentrate on branding, design, and marketing functions (Gereffi, 1994).

The producer-driven versus buyer-driven dichotomy, while useful as a point of departure, should not be strictly and statically interpreted. First, some commodity chains may exhibit the tendency to move from one category to the other. In some producer-driven chains such as automobile, computer, and consumer electronics, producers are increasingly outsourcing portions of component manufacture. Sometimes, they even outsource supply-chain logistics and final assembly, and keep control of promotion and marketing of the brand names on which market access is based-a peculiar trait of buyer-driven chains. Second, this dichotomy does not adequately explain some of the characteristics of service chains and some of the changing features of chain governance that relate to e-commerce operations. This has led Gereffi $(2001 a, b)$ to explore the possibility that another category of governance is emerging, the "infomediary-driven" chain. He also entertains two other possibilities: (a) that ecommerce and the internet may accelerate the tendency to make all chains more buyer driven; or (b) that e-commerce may just be captured by established leaders in both producer-driven and buyer-driven chains.

The fourth dimension of GCCs, the institutional framework surrounding the chain, is used to delineate the conditions under which key (or "lead") agents incorporate subordinate agents 
through their control of market access and of information - both technological and regarding markets (Gereffi, 1999b). Under the rubric of "institutional framework" Gereffi also discusses how subordinate participation in a GCC can provide indirect access to markets at lower costs than individual small-scale producers would face, and how technological information and learning-by-doing allow (the more favored) producers to move up the chain hierarchy. This suggests that participation in a GCC is a necessary, but not sufficient, condition for subordinate agents to upgrade, and one which involves acceptance of terms defined by key agents as a condition for participating in the chain, especially for those aiming to progress toward higher (technology, value added) positions in the chain (Gereffi, 1999a, p. 39; see also Gibbon, 2001a; Humphrey \& Schmitz, 2000; Tam \& Gereffi, 1999).

The GCC approach has generated a number of case studies. Although GCC theory originally centered on analyses of the manufacturing and service sectors, ${ }^{3}$ it has recently started to be applied to agro-food systems as well. ${ }^{4}$ Agricultural commodities tend to fall into the category of buyer-driven chains, ${ }^{5}$ in which large retailers in industrialized countries, brandname merchandisers, and international trading companies are the key actors in setting up decentralized networks of trade in developing countries. Because of the changes in distribution and retailing in industrialized countries since the $1980 \mathrm{~s}$, agricultural production and trade have involved an increasingly heterogeneous combination of firms, types of ownership, size, and relative access to markets. Therefore, a commodity-based analysis can provide better insights on the emerging configurations of agricultural trade than a sectoral approach (Raynolds, 1994, pp. 143-144; see also Raikes, Jensen, \& Ponte, 2000).

The GCC approach emphasizes the power of different constellations of lead firms and how interactions between these firms determine some of the specific organizational features of trade. Analyses of commodity markets (including coffee) based on neoclassical economics consider trade in isolation from investment, finance and other relations between parties. They also assume that both participants and transactions are separate and independent from each other. These constraining assumptions generate trade patterns that are determined by each country's endowments of production factors (see Raikes et al., 2000). Other contributions, while acknowledging imperfect competition and information asymmetries, still tend to focus on the reasons for the existence of institutions (notably transaction costs and barriers to entry) and perceive institutions primarily as regrettable departures from free trade (Raikes et al., 2000). Finally, political science approaches employing a rules-based version of neoinstitutional economics (for coffee, see Bates, 1997) examine institutions, but have relatively little to say about the internal organization of commodity trade.

The analysis of the coffee-marketing chain is particularly important in understanding the political economy of development for a variety of reasons. First, over $90 \%$ of coffee production takes place in developing countries, while consumption happens mainly in industrialized economies. ${ }^{6}$ Therefore, the production-consumption pattern provides insights on NorthSouth relations. Second, for most of the post-WWII period coffee has been the second most valuable traded commodity after oil. ${ }^{7}$ Third, attempts to control the international coffee trade have been taking place since the beginning of the 20th century, making coffee one of the first "regulated" commodities. Fourth, a number of developing countries, even those with a low share of the global export market, rely on coffee for a high proportion of their export earnings. Coffee is a source of livelihoods for millions of smallholders and farm workers worldwide. ${ }^{8}$ Fifth, producing country governments have historically treated coffee as a "strategic" commodity; they have either directly controlled domestic marketing and quality control operations or have strictly regulated them - at least until market liberalization took place in the 1980s and 1990s.

Not all aspects and "nodes" of the coffee commodity chain are covered in this paper, for obvious space limitations. The paper aims at mapping the general development of the chain from the producer to the retail levels and focuses on selected global issues. Detailed analyses of domestic and local experiences can be found elsewhere (Losch, 1999; Pelupessy, 1999; Ponte, 2002a).

\section{THE GLOBAL COFFEE CHAIN}

Coffee goes a long way and changes many hands from bean to cup (see Figure 1). Historically, Brazil and Colombia have been top world coffee producers. In the 1990s, however, 


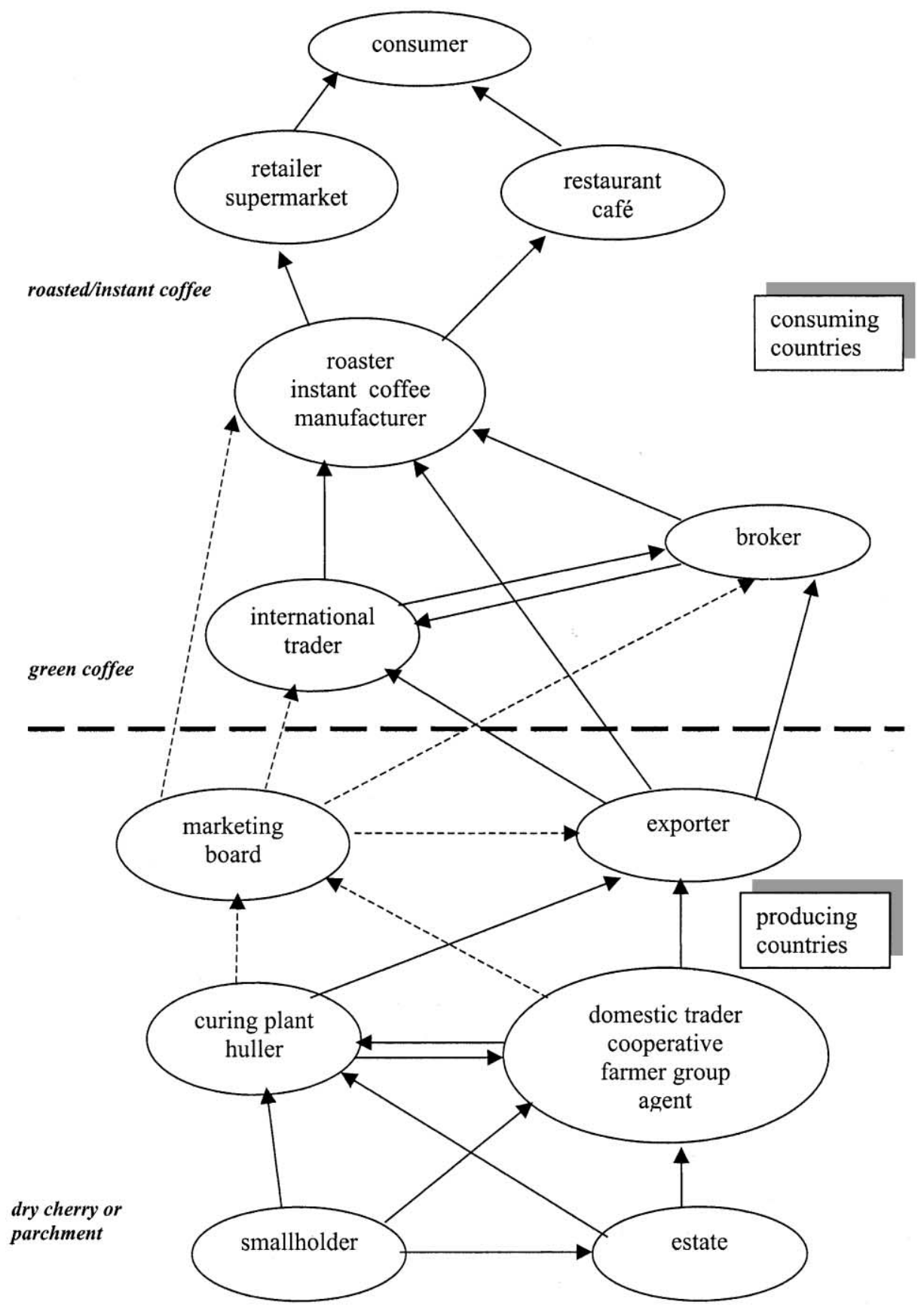

Figure 1. General structure of the global coffee-marketing chain. Note: With market liberalization, dotted links are disappearing.

the situation changed with the fast growth of which has contributed to the dramatic drop coffee production in Vietnam (see Table 1), in international coffee prices of the late 1990s 
Table 1. Total production of top 10 ICO-exporting members (ranked by 1999/2000 production); crop years 1995/96-2000/01 (thousands of 60-kg bags) ${ }^{\mathrm{a}}$

\begin{tabular}{lcccccccc}
\hline $\begin{array}{l}\text { Crop year } \\
\text { commencing }\end{array}$ & $\begin{array}{c}\text { Type of } \\
\text { coffee }\end{array}$ & 1995 & 1996 & 1997 & 1998 & 1999 & $\begin{array}{c}2000 \\
\text { (estimates) }\end{array}$ & $\begin{array}{c}\text { Share of world } \\
\text { production } \\
\text { (1999) }\end{array}$ \\
\hline Total & & 85,647 & 102,495 & 95,969 & 106,508 & 114,218 & 112,901 & \\
& & & & & & & \\
Brazil & (A/R) & 15,784 & 27,664 & 22,756 & 34,547 & 32,353 & 31,100 & 28.3 \\
Vietnam & (R) & 3,938 & 5,705 & 6,915 & 6,947 & 11,264 & 11,350 & 9.9 \\
Colombia & (A) & 12,878 & 10,876 & 12,211 & 11,088 & 9,336 & 12,000 & 8.2 \\
Mexico & (A) & 5,527 & 5,324 & 5,045 & 5,051 & 6,442 & 6,338 & 5.6 \\
Indonesia & (R/A) & 5,865 & 8,299 & 7,759 & 8,463 & 6,014 & 7,300 & 5.3 \\
Côte d'Ivoire & (R) & 2,532 & 4,528 & 3,682 & 2,042 & 5,463 & 4,167 & 4.8 \\
India & (A/R) & 3,727 & 3,469 & 4,735 & 4,372 & 5,407 & 4,917 & 4.7 \\
Guatemala & (A/R) & 4,002 & 4,524 & 4,218 & 4,892 & 5,201 & 4,500 & 4.6 \\
Ethiopia & (A) & 2,860 & 3,270 & 2,916 & 2,745 & 3,505 & 3,683 & 3.1 \\
Uganda & (R/A) & 3,244 & 4,297 & 2,552 & 3,298 & 3,097 & 3,200 & 2.7 \\
\hline
\end{tabular}

Source: ICO (2001b).

${ }^{\mathrm{a}} \mathrm{A}=$ Arabica; $\mathrm{R}=$ Robusta.

Table 2. Exports by major ICO-exporting member to all destinations (60-kg bags)

\begin{tabular}{lc}
\hline & March 2000 -February 2001 \\
\hline Colombian Milds & $11,539,133$ \\
Colombia & $9,499,242$ \\
Kenya & $1,214,199$ \\
Tanzania & 825,692 \\
Other Milds & $28,059,771$ \\
Guatemala & $4,771,031$ \\
Mexico & $4,659,096$ \\
India & $4,460,021$ \\
Honduras & $2,915,806$ \\
& $19,999,823$ \\
Brazilian Naturals & $18,154,618$ \\
Brazil & $1,834,205$ \\
Ethiopia & $29,008,946$ \\
Robustas & $11,958,220$ \\
Vietnam & $5,793,381$ \\
Côte d'Ivoire & $5,248,067$ \\
Indonesia & $2,641,651$ \\
Uganda & $88,607,673$ \\
Total & \\
\hline
\end{tabular}

Source: ICO (2001a).

(see below). In 1999/2000 Vietnam replaced Colombia as the world second largest producer. The ICO categorizes exports by type of coffee. As we can see in Table 2, Mild Arabica coffees are divided into "Colombian Milds" and "Other Milds." Colombian Milds comprise coffees produced in Colombia, Kenya and Tanzania. The main players in the Other Milds category are Guatemala, Mexico and India. "Brazilian Naturals" basically consist of Hard Arabicas from Brazil and Ethiopia. The last category includes Robusta coffees from all origins. Here, Vietnam is by far the main producer, but Côte d'Ivoire, Indonesia and Uganda are also major players. ${ }^{9}$ In normal supply conditions, market prices are highest for the Colombian Milds category, followed by Other Milds, Brazilian Naturals, and finally the wide spectrum of Robustas (McClumpha, 1988, p. 14).

Among consuming countries, Scandinavian countries (which have the highest level of consumption per capita in the world) and Germany prefer Mild Arabica coffees in their blends. Robusta coffee is a key component in espresso blends and darker roasts, therefore important in Southern Europe. The US and UK markets prefer lighter roasts in general, but require a wide spectrum of qualities. Historic trading links are still important in shaping the international coffee trade. A sizeable proportion of East African coffee finds its way to Germany and the UK. France maintains close links with Côte d'Ivoire and other Francophone countries. Dutch trading links with Indonesia remain important as well (McClumpha, 1988, p. 12).

Most international coffee trade consists of "green" coffee packed in $60-\mathrm{kg}$ bags. ${ }^{10}$ Green coffee is available to buyers either directly from its origin or via the spot markets in the United States and Europe. In theory, physical coffee can also be accessed to via the futures market, but this happens only rarely. The purpose of these markets is to provide hedging against risk rather than being a supply source (McClumpha, 1988, p. 8). Two sets of international 
coffee prices are available: (a) ICO-published prices: these are indicators of the physical trade, where each contract refers to a specific quality, origin, shipment, currency and destination; and (b) prices determined by futures markets: these are short-term syntheses of market fundamentals (production, consumption and stocks) and technical factors (hedging, trend following, reactions to trigger signals). Prices in the physical trade of Arabica coffees from various origins are set as differentials in relation to the futures price quoted at the New York Coffee, Sugar and Cocoa Exchange. The reference price for Robusta coffees is set at the London International Financial Futures and Options Exchange.

The international coffee market is characterized by relatively low price elasticities of supply and demand (McClumpha, 1988). Supply elasticities are low in the short run and higher in the long run because it takes at least two years for new trees to be productive and several others before they reach full production levels. Therefore, the supply response in the short term is possible only by changing the quantity of resources used for inputs and labor application, not by increasing the productive area - a feasible option for annual crops. Demand elasticities are also low, with coffee demand dropping significantly only at times of large increases of coffee prices. The peculiar characteristics of the price elasticities of supply and demand lead to highly variable prices in the world coffee market. A situation of supply shortage results in high coffee prices without a significant reduction of consumption. Likewise, supply reacts slowly in the short run while new plantings take place. In the long run, this leads to a higher than necessary response as new coffee trees mature. A situation of supply shortage may then be followed by one characterized by oversupply and low prices. An opposite bust period then begins - usually lasting longer than the boom period (Daviron, 1993; McClumpha, 1988).

Another important feature of the coffee market is that consumption tends to increase as income rises, but levels off at the highest income levels. For this reason, the coffee market is considered "mature" due to the relatively stable and low level of growth of consumption-about 1\% per year in 1987-97 (van Dijk, van Doesburg, Heijbroek, Wazir, \& de Wolff, 1998). Low levels of growth of consumption have led roasters and retailers to invest in product innovation and segmentation in order to increase value added and also in efforts to "cultivate" markets where the potential for growth of consumption is most promisingespecially Eastern Europe and the traditionally tea-drinking countries of Asia (van Dijk et al., 1998).

\section{CHANGING TRADE REGIMES}

(a) The international coffee agreements

Coffee was one of the first commodities for which control of world trade was attempted, starting in 1902 with the "valorization" process carried out by the Brazilian state of São Paulo. This process involved state action to raise the price of coffee, which was made possible at that time by the large share of production (between $75 \%$ and $90 \%$ ) of São Paulo in terms of world coffee production (Lucier, 1988, p. 117). PreWWII attempts at manipulating the world coffee market were all centered around Brazil. In the post-war period, control schemes involved other Latin American countries as well. The first international coffee agreement (ICA) was finally signed in 1962 and included most producing and consuming countries as signatories. Under the ICA regulatory system (196289), a target price (or a price band) for coffee was set, and export quotas were allocated to each producer. When the indicator price calculated by the ICO rose over the set price, quotas were relaxed; when it fell below the set price, quotas were tightened. If an extremely high rise of coffee prices took place (as in 197577), quotas were abandoned until prices fell down within the band. Although there were problems with this system, most analysts agree that it was successful in raising and stabilizing coffee prices (Akiyama \& Varangis, 1990; Bates, 1997; Daviron, 1996; Gilbert, 1996; Palm \& Vogelvang, 1991).

The relative success of the regime has been attributed to various factors: (i) the participation of consuming countries in the working of the quota system; (ii) the existence of producing countries as "market units," where governments were in control of decisions concerning exports; (iii) Brazil's acceptance of a shrinking market share that resulted from successive ICAs; and (iv) a common strategy of import substitution in producing countries, which required maximum mobilization of export earnings - therefore high commodity prices (Daviron, 1996, pp. 86-89). 
At the same time, the ICA system was undermined by free-riding and squabbling over quotas. Other problems were the increasing volume of coffee traded with (or through) nonmember importing countries (at lower prices), the continuing fragmentation of the geography of production, and the increasing heterogeneity of development models - as Brazil and Indonesia moved toward a more export-oriented industrial strategy (Daviron, 1993, 1996). Furthermore, quotas were relatively stable because they were costly to negotiate. As a result, the mix of coffee supplied by producers tended to remain stable, while in the 1980s consumers in the United States progressively switched from soluble coffees (that employ a high proportion of Robusta) to ground coffees (that use a higher proportion of Arabicas). The rigidity on the supply side worried roasters, who feared that competitors could get access to cheaper coffee from nonmember countries. This undermined their cooperation within the ICA system. Finally, the Cold War politics of the United States in relation to Latin America had changed in the 1980s. The United States did not perceive the left in Brazil as a real threat anymore, and the rigidity of quotas meant that the US administration could not punish its "enemies" in Central America (Bates, 1997, pp. 172-175). The combined result of these changes led to the failed renewal of the ICA in 1989.

\section{(b) The post-ICA regime}

The end of the ICA regime has profoundly affected the balance of power in the coffee chain. From a fairly balanced contest between producers and consumers within the politics of the commodity agreement, market relations shifted to a dominance of consuming countrybased operators (including their agents based in producing countries) over farmers, local traders and producing country governments. This has been accompanied by lower and more volatile coffee prices, a higher proportion of the income generated in the chain retained in consuming countries, and a declining level of producerheld stocks.

In relation to price levels, we can observe that the average real indicator price for 1990-93 was only $42 \%$ of the average of the final four years of ICA activity (1985-88). Even accounting for the price rise of 1994-97 (due to frost and drought in 1994-95 in Brazil, and the speculative hike of 1997), the average composite price for 1994-97 was still 20\% below 1985-88 (Gil- bert, 1998). In 1993, with the establishment of the Association of Coffee Producer Countries (ACPC), ${ }^{11}$ producing countries started again attempts to re-install some control over supply flows through an export retention scheme. However, the process of liberalization of domestic coffee marketing in producing countries has made it more difficult for them to control stocks and the flow of exports. In addition, the scheme was lacking proper monitoring and punitive clauses. Some of the major producers did not join the scheme, ${ }^{12}$ and other member countries withdrew from it in 1998-99. Finally, during the same season, Brazil exceeded its quota by six million bags.

Chronic oversupply, due to technical innovations and new planting, also contributed to the generally decreasing level of international coffee prices experienced in the last decade. Global production in 2000-01 was over 110 million bags, the third consecutive year in which world output exceeded 100 million bags (see Table 1). Stocks in consumer markets, the most obvious index of coffee availability, have been rising (Prudential Securities Futures Research: Coffee, June 28, 2000). ${ }^{13}$ In May 2000, the ACPC adopted a new retention plan that started to be operative on October 1, 2000. The plan targeted the retention of $20 \%$ of total world production as long as the 15-day moving average of the ICO composite price indicator was below 95 cents per pound. Major nonmember producers provided their support to the plan. But, participation in the retention plan by nonmembers was largely voluntary. Some of these countries stated that retention had to be cost free. Mexico, for example, aimed at achieving "export retention" by increasing consumption in government-controlled institutions. Forecasts also indicated a strong increase in production for 2001-02, which would have implicated a further increase in export retention levels. The retention plan did not include provisions for destroying stocks; therefore, it did not address the fundamental problem of overproduction. Even though year-to-year fluctuations of the global production volume are inherent in the world coffee market, the longterm trend is generally perceived on the upward side. As a result of these problems, the retention plan did not succeed in raising prices. The average ICO composite price indicator went from 69.2 cents per pound in May 2000 (when the retention plan was signed) to 56.4 cents in October 2000 (when the plan officially started). By October 2001 (when the plan was 
abandoned), the average composite price had dropped to 42.2 cents per pound (ICO, 2001a).

In the 1990s, lower coffee prices have also been accompanied by a higher level of price volatility. Price volatility is not a new phenomenon in the coffee market. A major "traditional" factor in volatility is that coffee yields are vulnerable to changes in temperature and rainfall, as well as disease. Frosts and drought in Brazil have normally led to sudden upward movements in coffee prices. The delay between new planting and production can also contribute to magnifying the price movements in the coffee cycle. However, something qualitatively different took place in the 1990s. The final eight calendar years of ICO activity were characterized by monthly nominal price variability of $14.8 \%$. This indicator almost doubled to $37 \%$ during 1990-97 (Gilbert, 1998) and then further increased to $43 \%$ during $1998-2000 .{ }^{14}$

Higher price volatility in the coffee market is not only linked to the end of price stabilization mechanisms that were built in the ICA quota system, but also to increased activity in the coffee futures market. In 1980, the amount of coffee traded in the futures market was only around four times the coffee traded in the physical market. By the early 1990s, the ratio had risen to 11 times (van Dijk et al., 1998, p. 45). Futures markets allow market transactors to fix their prices in advance of delivery so that they can hedge their price volatility risk. Yet, futures contracts lose much of their hedging function when the price of futures contracts is too volatile. The volatility of futures prices is normally triggered by market "fundamen- tals" (demand-supply-stock relationships), but is magnified by speculative activity. In the last decade, investment funds have become increasingly active in commodity markets. Because managed funds operate on the basis of trend-following, "trigger signals" (which may not necessarily be linked to the actual conditions of supply and demand) tend to cause larger movements in and out of the market than if the market was operated by the coffee industry alone (Crowe, 1997). On the one hand, this additional activity increases liquidity in the market. On the other hand, the increased price volatility that ensues affects those actors who do not have access to hedging instrumentsfarmers and small-scale traders in producing countries (Gilbert, 1996).

The collapse of the ICA regime and increased consolidation in the coffee industry (see Section 5) have also affected the distribution of total income generated along the coffee chain. ${ }^{15}$ Talbot (1997a, pp. 65-67) estimates that, in the 1970 s, an average of $20 \%$ of total income was retained by producers, while the average proportion retained in consuming countries was almost 53\% (see Figure 2). ${ }^{16}$ Between 1980-81 and 1988-89, producers still controlled almost $20 \%$ of total income; $55 \%$ was retained in consuming countries. After the collapse of ICA in 1989, the situation changed dramatically. Between 1989-90 and 1994-95, the proportion of total income gained by producers dropped to $13 \%$; the proportion retained in consuming countries surged to $78 \%$. ${ }^{17}$ This represents a substantial transfer of resources from producing to consuming countries, irrespectively of

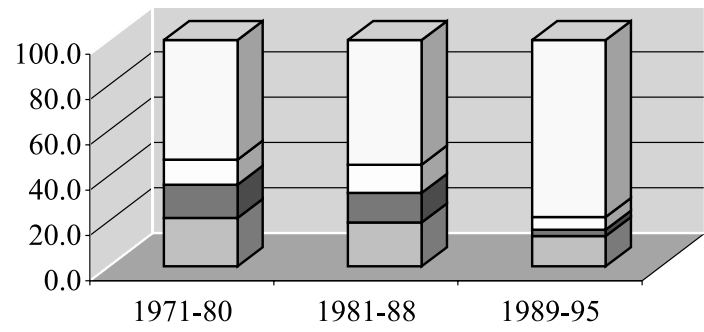

\begin{tabular}{|l}
\hline value added in \\
consuming \\
countries \\
$\square$ transport costs \\
and weight loss \\
\\
$\square$ value added in \\
producing \\
countries \\
$\square$ price paid to \\
growers
\end{tabular}

Figure 2. Distribution of coffee income along the coffee chain (1971-80 to 1989-95), in percentage. Source: Adapted from Talbot (1997a, pp. 65-67). Note: Coffee income=weighted average of retail prices in ICO member importing countries, expressed in green bean equivalents. Monetary values of total coffee income for the periods indicated in this figure: 1971-80 (262.6 US cts/lb); 1981-88 (363.5 US cts/lb); 1989-95 (435.8 US cts/lb) (calculated from Talbot, 1997a, pp. 65-67). 
price levels. The share of income retained by producers in the last two-three years is likely to have dropped further due to the current situation of oversupply and low prices for green coffee and the ability of roasters to maintain retail prices at relatively stable levels. While green coffee prices almost halved between December 1999 and January 2001 (see Figure 3), average retail prices in the US decreased by $4 \%$ (ICO, 2001a). This suggests that not only gross margins - but also profits - have increased for roasters.

Finally, the end of the ICA regime meant that the bureaucracy that was needed to monitor exports and ensure compliance with quota restrictions was no longer needed. This, coupled with the general switch in economic thinking in the 1980s and 1990s away from public intervention in markets, led to the dismantling of coffee boards, institutes and other quasi-governmental bodies that regulated export sales. As a result, the capability of producing countries to control exports and to build up stocks has decreased. Producer-held stocks are roughly at the lowest level in 30 years. ${ }^{18}$

\section{MARKET POWER AND CORPORATE STRATEGIES}

In Section 4 I have argued that there has been a general shift of power from producing to consuming countries in the coffee-marketing chain following the end of the ICA regime. Power relations between producers and buyers have also become more complex. Domestic market liberalization in producing countries entails that states as such cannot be considered "market units" anymore (Daviron, 1996). Grower organizations have not been able to substitute governments as organizers of coffee exports. "Local" exporters have not been able to raise necessary funds to compete with international traders, and have now either disappeared or allied themselves with international traders. The general trend has been a strengthening of the position of roasters vis à vis other actors.

International traders went through considerable restructuring in the last two decades. Mid-sized traders with unhedged positions suffered major losses. They also found themselves too small to compete with larger ones. As a result, they either went bankrupt, merged with others, or were taken over by the majors (Prudential Securities Futures Research: Coffee, June 28, 2000). ${ }^{19}$ Therefore, the market has become more concentrated. In 1998, the two largest coffee traders (Neumann and Volcafé) controlled $29 \%$ of total market share, and the top six companies 50\% (see Figure 4). At the same time, prospects are good for smaller and specialized companies that trade in the specialty coffee market (high quality and specific origins). With some exceptions, there has been little vertical integration between roasters and

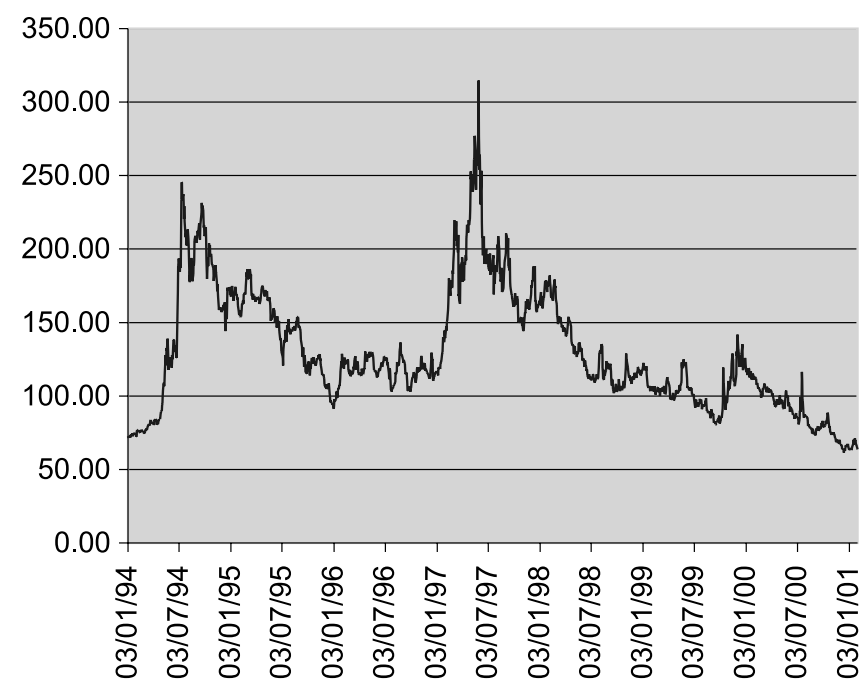

Figure 3. New York coffee futures prices; nearby contract (US cts/lb) 1994-2001. Source: CSCE (2001). 


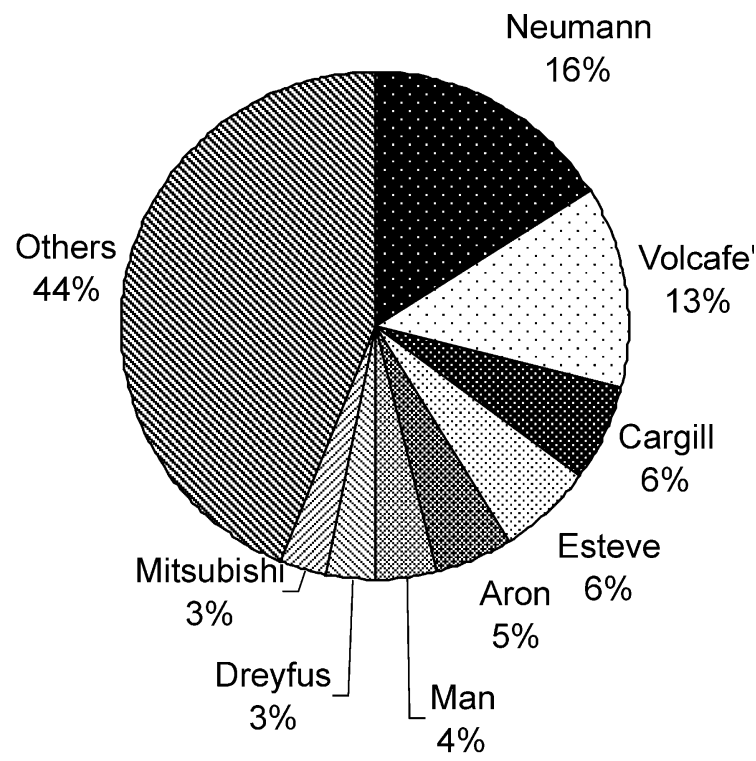

Figure 4. Green coffee market share by international trade company (1998), in percentage. Source: van Dijk et al. (1998, p. 34).

international traders (van Dijk et al., 1998, pp. 34-35). ${ }^{20}$

The level of concentration in the roaster market has reached a level even higher than for international traders. Figure 5 shows that the top two groups combined (Nestlé and Philip Morris) control $49 \%$ of the world market share for roasted and instant coffees. The top five groups control $69 \%$ of the market. Nestlé dominates the soluble market with a market share of 56\% (van Dijk et al., 1998, p. 34). International traders argue that roasters have gained increasing control of the marketing chain in recent years because of oversupply, increased flexibility in blending, and the implementation of "supplier-managed inventory" (SMI).

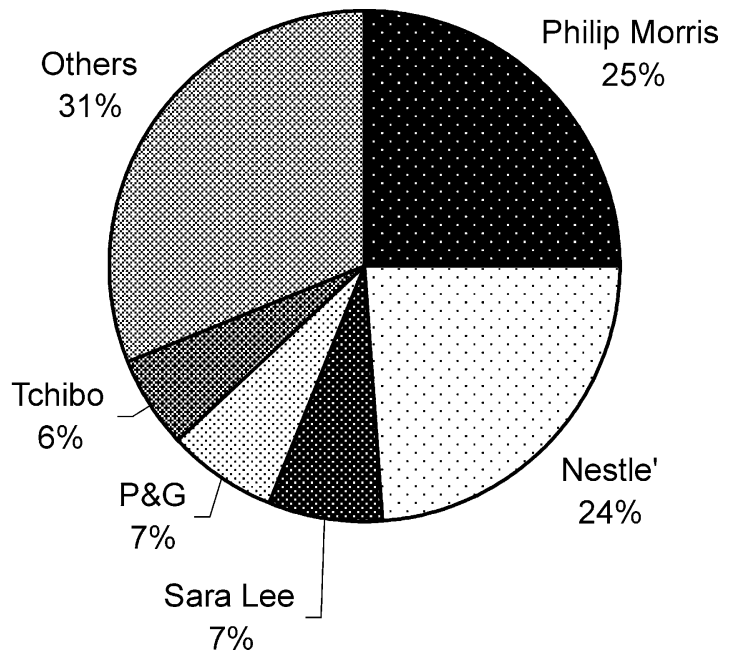

Figure 5. Market share of roasting and instant manufacturing companies (1998), in percentage. Source: van Dijk et al. (1998, p. 52). 
It is actually not clear what were the precise motivations behind the adoption of SMI systems by roasters. One interpretation is that SMI allows roasters to minimize costs by transferring the working capital costs of inventory holding to trading houses. However, successful management of SMI requires at least two key conditions: (a) a close balance between supply and demand, or a supply surplus; and (b) supply conditions of various types and origins of coffee that do not force roasters to change blends in ways that would not satisfy their consumers. ${ }^{21}$ According to Lodder (1997), these factors were not present when roasters started to apply SMI in 1997. Therefore, they found themselves short of Arabica and scrambled for coffee purchases, triggering a panicbuying situation that led to a major price hike. In later years, however, roasters seem to have been able to implement a more cautious SMI system successfully.

A second interpretation for the adoption of SMI is that roasting companies quoted in stock markets need to contain the size of inventories and of circulating capital within "optimal" parameters set by financial analysts - large inventories and a high ratio of circulating capital being normally interpreted as indicators of inefficiency. When roasters started carrying out SMI, the futures market was in "backwardation." In that situation, carrying stocks was costly because forward future contracts were valued less than nearby positions. Therefore, applying SMI also made sense for roasters in terms of financial returns. However, the coffee market has been "carrying" in more recent years, which means that forward contracts are valued more than nearby contracts. In this situation, if the costs of stocking (warehousing, finance, and insurance) are lower than the spread between positions, the holder of stocks can make a profit just by holding inventory.

In sum, outsourcing stock management during a period of backwardation could be interpreted as an indicator of the increasing power of roasters over international traders. Sticking to SMI in a carrying market should not however be seen as a revival of international traders in their power relations with roasters, but rather as a sign of captivity of quoted roasting companies to the logic of financial markets. In any case, as a result of the adoption of SMI by roasters - and in combination with market liberalization in producing countries-international traders have strengthened their supply network. This has taken place through co- ordination (mostly financing) or vertical integration with local exporters. In some countries, international traders have moved upstream $^{22}$ all the way to domestic trade and in some cases to estate production (Akiyama, 2001; Losch, 1999; Ponte, 2002a). International traders are likely to continue investing in operations in origin countries so that they can cater to the needs of major roasters.

Roasters seem to have little interest in vertical integration upstream in the current market conditions. They seem better off concentrating on marketing and branding, while leaving supply management to a network of independent traders - even if, in periods of carrying markets, this means foregoing a source of profit. Some roasters (such as Nestlé) are said to source not only from a variety of international traders, but also directly from some "local" exporters. The aim is to allow these exporters to compete with international traders in strategic origins. This allows the roaster to be less dependent on any actor, and especially on major traders. Furthermore, more flexibility in developing blending formulas has made roasters less vulnerable to shortages of particular types of coffee in recent years. Shortages of Colombian coffee have been offset by greater use of Central American Milds. Another example of substitution is the greater use of Mexican beans in place of Brazilian. The new technique of steam-cleaning Robusta allows roasters to improve its quality and to substitute poorer Arabicas with premiumgrade Robustas.

Another trend that seems to be emerging in the industry is one toward the creation of a system of first-line and second-line suppliers, subject to price premia and discounts. Major roasters tend not to accept coffee for their blends from countries that cannot guarantee a reliable minimum amount of supply - in the case of Arabica, around 60,000 tons a year (Raikes \& Gibbon, 2000). As a result, on the one hand, minor producers may become increasingly marginalized in the future - without necessarily increasing the bargaining power of major producers vis a vis roasters. On the other hand, this has pushed some international traders to be (directly or indirectly) involved in domestic trade in major producing countries even though these operations may not be profitable (Uganda, for example), as long as they can satisfy their major roaster clients (Ponte, 2002a).

As a result of these factors, no significant forms of coordination between international 
traders and roasters have emerged so far. The "traditional" market, as long as there is oversupply and roasters can manage SMI effectively, is likely to remain governed by armslength relationship and/or by forward contracts of short duration (under 12 months). The next section will show that in the specialty coffee sector, where brand development in relation to a particular origin or estate requires security of supply, roasters may be pushed toward closer forms of coordination with international traders and exporters in the near future. ${ }^{23}$

\section{THE "LATTE REVOLUTION"? SPECIALTY COFFEE AND THE CHANGING WORLD OF COFFEE CONSUMPTION}

Globally, most coffee for in-home consumption is purchased in supermarkets. The food retail sector is highly concentrated in the United States, the United Kingdom and Northern Europe and plays a dominant role in the food marketing chain (van Dijk et al., 1998). Yet, through consolidation and with massive investment in advertising their brands, roasters have managed to keep control of the coffee chain (van Dijk et al., 1998). This happened in spite of the development of private coffee labels by supermarkets. As a result, supermarkets' retail margins for coffee have remained generally lower than for the average food portfolio. In some countries, such as the United States, retailers sell coffee even at a loss in order to "generate traffic." Retailers need to stock coffee because consumers expect them to do so. They can attract customers with relatively cheap coffee and entice them to buy other (higher-margin) items during their visit (Dicum \& Luttinger, 1999; Pendergrast, 2001; van Dijk et al., 1998). Furthermore, coffee sales have recently moved into even lower profit margin outlets, such as warehouse and discount stores. In 1997, 10\% of total retail coffee purchases in the United States were made at Wal-Mart (Dicum \& Luttinger, 1999, pp. 114, 159).

Does this mean that roasters will continue to dominate the coffee chain in the future? In Section 5, I have argued that entry barriers in the "traditional" coffee-marketing chain have increased in both trading and roasting, and that strategic choices made by roasters in the last decade have shaped the reactions of all other actors upstream. Recent signals, however, suggest that a fragmentation of the market is taking place. The emergence of new consumption patterns, with the growing importance of "conscious" consumption, ${ }^{24}$ single origin coffees, the proliferation of café chains and specialty shops, and increasing out of home consumption poses new challenges to "traditional" roasters (van Dijk et al., 1998). They are used to selling large quantities of relatively homogeneous and undifferentiated blends of mediocre to poor quality. According to coffee industry analysts, these roasters have been slow in changing long-established ways of carrying out business and advertising.

Major coffee roasters lost their regional image and their focus on localized taste preferences a long time ago. In the United States, regional roasters such as Folgers, Hills Brothers, and Maxwell House became national in scope and then started being bought by food conglomerates as early as the post-WWII period (Dicum \& Luttinger, 1999; Pendergrast, 2001). ${ }^{25}$ When they became part of major industrial empires, coffee roasters had to move away from a focus on quality and locality. They started to concentrate on consistency in price, packaging and flavor. As a result, roasters homogenized blends. They started to use cheaper beans and cut down roasting times to reduce weight loss and mask the poor quality of the beans. Overall coffee quality decreased. As brand competition took the fore in corporate strategies in the United States, the product itself became of secondary importance (Dicum \& Luttinger, 1999). Homogenization and mass marketing of coffee further increased with the gaining importance of instant coffee after WWII. By competing almost exclusively on advertising, the major roasters stripped off coffee of most of its charm and appeal even as per capita consumption started to decline after 1962. On the contrary, in Europe coffee standards remained higher due to cultural factors and different patterns of consumption even after multinationals moved into the coffee market (Dicum \& Luttinger, 1999, pp. 116-163).

It is in the background of these changes that the specialty coffee industry emerged as an important player, first in the United States and later in Europe. One of the characteristics of specialty coffee is that it means different things to different people. Nowadays, the term covers basically all coffees that are not traditional industrial blends, either because of their high quality and/or limited availability on the producing side, or because of flavoring, packaging 
and/or "consumption experience" on the consumption side (ICO, ITC, \& CFC, 2000).

The evolution of specialty coffee cannot be appreciated without making a reference to the "Starbucks factor." Starbucks was founded in 1971 in Seattle, following the steps of Peet's, another quality roaster based in Berkeley. As other specialty operators, Starbucks spent most of the 1980s building a loyal customer base and "educating" consumers on the qualities of fine coffees. The breakthrough that made Starbucks a stunning success was creating a café atmosphere where customers could hang out and consume an "experience" at a place that was neither home nor work. This happened at the same time as other consumer products moved from mass-production and marketing to being recast as more authentic, flavorful and healthy (micro-brewed beer, specialty breads, organic vegetables). By combining "ambience" consumption and the possibility for consumers to choose type, origin, roast, and grind, Starbucks managed to de-commoditize coffee. It sold coffee "pre-packaged with lifestyle signifiers" (Dicum \& Luttinger, 1999, p. 153). By 1997, Starbucks was operating 2,000 outlets (mostly directly owned) in six countries. In 1998, it entered the European market through the acquisition of the London-based Seattle Coffee Company and plans the opening of 500 outlets in the continent by 2003 (Starbucks, 2001).

Accompanying the growth in café chains, there has also been an explosive increase in the number of roasters in the United States, although the smallest 1,900 roasters still control only $20 \%$ of the domestic market. As recently as 1987 , the three major roasting companies in the United States held almost $90 \%$ of the retail market. By 1993 they had lost 12\% of the market share to Starbucks, other regional cafés and specialty roasters (Dicum \& Luttinger, 1999). Specialty coffee consumption is growing rapidly in "traditional" consuming countries, whereas regular coffee consumption is stagnating. It is estimated that the number of Americans drinking specialty coffees on a daily basis grew from 20 to 27 million in 2001, up from only seven million in 1997 (Financial Times, April 27, 2001).

Traditional roasters have been slow in responding to this new phenomenon. They have put darker roasts in the market and created their own specialty brands, but consumer response has been poor so far (Dicum \& Luttinger, 1999). One interesting inroad that some industrial suppliers are experimenting with is offering "high-quality" coffee roasted on the spot by computerized roasters in large discount stores. In this case, it is not the intrinsic quality of coffee that makes it "better." These coffees are mediocre and are bought in bulk. Their "selling point" is that they are freshly roasted. They also sell at much cheaper prices than in specialty stores. Another likely future strategy for the mainstream roasters to conquer back market share will be acquisition of smaller specialty roasters and café chains (Dicum \& Luttinger, 1999).

Starbucks, on its side, has adopted fairly mainstream corporate strategies. It has acquired competing chains, and has opened outlets in neighborhoods with traditional cafés to drive them out of business (Wal-Mart style). It has also entered into joint marketing programs with other corporate giants (PepsiCo, Barnes \& Noble, Capitol Records, United Airlines). By becoming another large corporation and by providing a homogenized retail experience with a consistent but not exceptionally good product, Starbucks has in many ways become the opposite of what independent coffee houses perceive themselves to be (Dicum \& Luttinger, 1999). Furthermore, as café chains consolidate, quality per se may not be as important in the future. If chains get bigger, they tend to (re)commoditize the supply chain and simplify business. Higher sales entail more centralized buying requirements and more difficult relations with smaller suppliers. They also entail more prominence for blends rather than "straight origins" (ICO, ITC, \& CFC, 2000). Therefore, more consumption of specialty coffee may not entail increased use of high-quality coffee.

The "Starbucks phenomenon" may have revitalized interest for coffee in consuming countries and new (higher value added) ways of consuming it. Still, it is unclear whether specialty coffee will be successful in permanently de-commoditizing coffee and in breaking the oligopoly held by a few roasting companies. It is also not certain whether the specialty coffee industry holds much promise for coffee producers, who are facing the lowest prices for green coffee in decades. What difference does it make to a smallholder if a consumer can buy a "double tall decaf latte" for $\$ 4$, or if specialty beans are sold at $\$ 12$ per pound in the United States if he/she gets less than 50 cents for the same pound of coffee? Since the coffee content of new coffee consumption experiences is very low (see Fitter \& Kaplinsky, 2001), the "latte 
revolution" may have more to do with milk (latte) than with coffee.

\section{COFFEE AND GCC ANALYSIS}

In this section, I provide a reading of the restructuring of the global coffee chain through the analytical categories of GCC. I also assess the insights offered by the coffee case study to wider debates that are taking place in the GCC literature. As explained in Section 2, Gereffi (1994, 1995) identifies four key dimensions of GCCs: the input-output structure, the geographical coverage, the governance structure, and the institutional framework. Tables 3 and 4 summarize changes and continuities within these dimensions in relation to two broad periods: the ICA regime (1962-89) and the postICA regime (1989-present). These two periods were selected for the sake of simplifying the analysis. However, even though the ICA ended in 1989, the regime shift did not occur overnight. Some of the forces that led to its transformation were already at work. Others changes took place later (the adoption of SMI, for example).

\section{(a) Governance}

The governance structure of the global coffee chain has clearly been transformed in the transition between the two regimes. During the ICA regime, the coffee chain was not particularly driven by any actor, nor was it possible to clearly state that producing or consuming countries controlled it. Entry barriers in farming and in domestic trade were often mediated by governments. The international coffee trade was regulated by the commodity agreement. The establishment of quotas and their periodic negotiation entailed that entry barriers for countries as producer units were also politically negotiated within the ICA mechanisms. Yet, the rise of power of roasters over international traders had already started to occur. This was reflected in the leadership structures of the coffee industry in consuming countries - where roasters played a key role - and meant that the trading firms' goal of maximum profits in the short term was being replaced by the search for an optimum expansion of activities on the part of roasters (Daviron, 1996).

Contrary to what claimed in another analysis of the coffee value chain (see Fitter \& Kaplinsky, 2001, p. 78), I would argue that the post-
ICA regime exhibits many of the characteristics of a buyer-driven chain. Strategic choices made by roasters in the last 10 years have shaped entry barriers not only in the roaster segment of the chain, but also in other segments upstream. Several indicators suggest an increase in the level of "drivenness." First, new requirements set by roasters on minimum quantities needed from any particular origin to be included in a major blend can be interpreted as setting entry barriers to producing countries. These barriers used to be set by governments on the basis of political negotiation under the ICA regime. Now, private firms set them on the basis of market requirements. Second, roasters have been able to devise new technological solutions to be less dependent on any type or origin of coffee. It is not clear yet how roasters have combined the minimum supply quantity strategy with more flexibility in product substitution, and which one of the two has relatively more weight in their global sourcing strategy. In any case, they both indicate a potential increase in the level of drivenness of the chain by roasters. Third, roasters have been able to set the terms of coffee supply with the implementation of SMI. The adoption of SMI has added new requirements for international traders to be part of the game. Guaranteeing a constant supply of a variety of origins and coffee types has prompted international traders to get even more involved in producing countries than they would have anyway as a result of market liberalization. Fourth, the persistent ability of roasters to keep retailer margins at low levels suggests that they are still the driving force in the chain even downstream. Countervailing tendencies are arising in the specialty market. These may not, however, be as threatening to main roasters as it seems because these large corporations always have the possibility of buying out significant specialty players. Moreover, as specialty coffee actors grow, they tend to streamline operations and homogenize products; therefore, they adopt some of the same supply strategies used by giant conglomerates.

\section{(b) The institutional framework}

The institutional framework within which the coffee chain operates has changed dramatically as well. The inherent stabilization forces of the ICAs and regulated markets in producing countries created a relatively stable institutional environment where rules were relatively clear, 
Table 3. Characteristics of coffee chain restructuring (input-output structure and geographies of production and consumption)

\begin{tabular}{|c|c|c|}
\hline & ICA regime (1962-89) & Post-ICA regime (1989-present) \\
\hline Geography of production & $\begin{array}{l}\text { At first concentrated in few large pro- } \\
\text { ducing countries (Brazil, Colombia); } \\
\text { later, increasingly dispersed with the } \\
\text { emergence of new producers }\end{array}$ & Fragmentation continues \\
\hline Entry barriers to production & $\begin{array}{l}\text { Low, due to government intervention } \\
\text { (input and credit supply, extension, } \\
\text { coffee cultivation campaigns, price } \\
\text { stabilization) }\end{array}$ & $\begin{array}{l}\text { Increased, due to government with- } \\
\text { drawal from the provision of services to } \\
\text { farmers (end of input supply schemes, } \\
\text { breakdown of research and extension } \\
\text { networks, end of price stabilization } \\
\text { mechanisms) }\end{array}$ \\
\hline $\begin{array}{l}\text { Characteristics of internationally } \\
\text { traded product }\end{array}$ & $\begin{array}{l}\text { Relatively homogeneous, but } \\
\text { distinguished by physical and intrinsic } \\
\text { qualities (the latter especially for } \\
\text { Mild Arabica) }\end{array}$ & $\begin{array}{l}\text { Bifurcated trend: increased homogeni- } \\
\text { zation of lower quality coffees, } \\
\text { especially Robusta (bulk export in } \\
\text { containers without bags); at the same } \\
\text { time, increased trade of small quantities } \\
\text { of specific high-end-quality beans } \\
\text { (Mild Arabica) }\end{array}$ \\
\hline \multirow[t]{2}{*}{ Entry barriers to trade } & $\begin{array}{l}\text { Domestic trade and export: high barri- } \\
\text { ers due to monopoly of marketing or } \\
\text { politically set domestic trade quotas }\end{array}$ & $\begin{array}{l}\text { Domestic trade and export: first, de- } \\
\text { creased entry barriers due to liberaliza- } \\
\text { tion; later, increased barriers following } \\
\text { the strengthening of international trader } \\
\text { operations in producing countries }\end{array}$ \\
\hline & $\begin{array}{l}\text { International trade: increasing due to } \\
\text { consolidation }\end{array}$ & $\begin{array}{l}\text { International trade: increasing entry } \\
\text { barriers in "fair-average-quality" } \\
\text { market due to further consolidation and } \\
\text { requirements set by roasters through } \\
\text { SMI; decreasing in the specialty market } \\
\text { due to fragmentation and the growing } \\
\text { importance of e-commerce sales }\end{array}$ \\
\hline $\begin{array}{l}\text { Distribution of total income } \\
\text { generated along the chain }\end{array}$ & $\begin{array}{l}\text { Relatively stable, with farmers getting } \\
\text { around } 20 \% \text { of the total, and consum- } \\
\text { ing country operators around } 50 \%\end{array}$ & $\begin{array}{l}\text { Shifted to the advantage of consuming } \\
\text { country operators }\end{array}$ \\
\hline Geography of consumption & $\begin{array}{l}\text { Concentrated in North America, West- } \\
\text { ern Europe and Japan }\end{array}$ & $\begin{array}{l}\text { Emergence of new markets } \\
\text { (Eastern Europe, China, East Asia) }\end{array}$ \\
\hline Typology of consumption & $\begin{array}{l}\text { Segmented by group of countries } \\
\text { (different coffee types and blends } \\
\text { catering for the USA/UK markets, } \\
\text { Southern Europe, Scandinavia, Central } \\
\text { Europe, Japan), but relatively } \\
\text { homogeneous consumption within } \\
\text { these geographical areas }\end{array}$ & $\begin{array}{l}\text { Increased fragmentation: multiplication } \\
\text { of types of product and blurring of } \\
\text { distinctive lines of preference between } \\
\text { different groups of countries; increasing } \\
\text { importance of "single origin" coffees }\end{array}$ \\
\hline
\end{tabular}

change politically negotiated, and proportions of generated income fairly distributed between consuming and producing countries. The relatively homogeneous form of trade limited the possibilities of product upgrading, but producing countries ensured product valorization through higher prices generated by the ICA. In the post-ICA regime, market relations have substituted political negotiation over quotas. Producing countries have disappeared as actors in these interactions, with the exception of not- so-successful retention attempts under the ACPC umbrella. The ICO has become a relatively empty institutional shell. Domestic regulation of coffee markets plays an increasingly weaker role. Relatively stable producer-negotiated and product-based quality conventions are increasingly giving way to conventions that are generally buyer established. As concerns "conscious" coffees, these conventions are based on (buyer-defined) process monitoring - as well as product specification. Product upgrading 
Table 4. Characteristics of coffee chain restructuring (governance structure and institutional framework)

\begin{tabular}{|c|c|c|}
\hline & ICA regime (1962-89) & Post-ICA regime (1989-present) \\
\hline $\begin{array}{l}\text { Governance structure of the } \\
\text { chain }\end{array}$ & $\begin{array}{l}\text { Low level of "drivenness;" increasing } \\
\text { concentration in roasting and trading } \\
\text { segments raises entry barriers, but } \\
\text { roasters are neither in the position to } \\
\text { dictate the terms of the trade to traders, } \\
\text { nor to set inclusion/exclusion thresholds; } \\
\text { control over the chain by any actor is } \\
\text { limited }\end{array}$ & $\begin{array}{l}\text { "Buyer-driven" (specifically, roaster- } \\
\text { driven); further consolidation in roasting; } \\
\text { oversupply; adoption of SMI by roasters } \\
\text { forces traders to integrate upstream; } \\
\text { vertical integration by traders made easier } \\
\text { by market liberalization in producing } \\
\text { countries }\end{array}$ \\
\hline
\end{tabular}

Vertical integration

Upgrading possibilities
Institutional framework (domestic)

Quality conventions

Producer-consumer country relations

Institutional framework (international)

\begin{abstract}
Not common; sometimes occurring in export/international trade links; more rarely into domestic trade and processing
\end{abstract}

Increasing; international traders integrate into export, processing, domestic trade and sometimes even estate production; vertical integration much more limited in the roaster-international trader link
In relative equilibrium; mediated through Absence of formalized relations; the ICAs

Strong: international trade regulated by ICAs

Strong: markets monopolized by marketing boards, or regulated by stabilization funds and quasigovernmental producer associations

International-level: product-based; set in negotiation with producing-country sellers (and/or marketing boards) and maintained via instrument-based testing and inspection, cup testing, and certification of the product; in general, quality assessed by the buyer ex-post

Domestic-level: set by a regulatory agency; includes specific quality control procedures along the chain consuming country domination

Weak: end of ICA; producing country cartels fail to set up effective quota or retention schemes; futures market increasingly de-linked from market fundamentals

Weak: government and quasi-government institutions retreat into oversight functions or are eliminated altogether; trade associations fill only part of the formal institutional vacuum

International-level: increasing importance of conventions defined by buyers; process monitoring (in addition to product testing) becomes important for fair trade, organic, shade-grown coffees; quality increasingly assessed by buyers ex-ante Domestic-level: increasingly set by buyers; formal rules of quality control remain but are increasingly disregarded

Limited; undifferentiated trade; however, Potentially increasing through marketing producing countries achieve product of "conscious" coffee and direct e-comvalorization through higher international merce sales; openings in specialty markets prices provided by the ICA more suitable to estates than smallholders possibilities have increased through the fragmentation of consumption patterns, marketing of specialty coffee and e-commerce sales. Yet, openings in specialty markets so far have been more suitable to estates than smallholders.

\section{(c) The insights of coffee to GCC analysis}

The coffee case study provides a number of insights to GCC analysis. Here, I will examine three key aspects: (i) the significance of the externalization of noncore functions that is manifested in several buyer-driven chains; (ii) the importance of including regulation in the analysis of any chain; and (iii) the significance of different levels of drivenness and different forms of coordination within buyerdriven chains.

In the early GCC literature, outsourcing of supply management and/or manufacturing was often interpreted as an instance of externalization of low-profit and noncore functions upstream that is peculiar to many buyer-driven chains - although increasingly relevant in some producer-driven chains as well. More recently, Sturgeon $(1999,2001)$ questioned this interpretation. He argued that the functions externalized by brand-name firms to contract 
manufacturers in "turn-key" production networks are not necessarily low profit and that they do not entail a "captive" position of suppliers. "Turn-key" systems are common in electronic products, but also emerging in the auto parts industry, food processing and pharmaceuticals. In the agricultural sector, they seem to be emerging in the cocoa-chocolate complex, where branded chocolate manufacturers are increasingly outsourcing the supply of cocoa intermediate products (Fold, 2001). This has not happened in the coffee chain, where roasters have maintained the processing (roasting) function. However, the experience of SMI in the coffee industry seems to lend weight to Sturgeon's argument in that outsourcing is not necessarily implemented to externalize lowprofit functions - in a period of carrying coffee futures market, supply management can be highly profitable. Yet, roasters have maintained the control of key decisions in supply management, therefore keeping international traders in a "captive" position.

The coffee case study also shows that the end of the commodity agreement and market liberalization in producing countries were among the factors shaping key transformations in the chain. ${ }^{26}$ GCC analysis has so far focused on how business (particularly sourcing) strategies influence governance and institutional structures of commodity chains - relatively neglecting the role of regulation. Finally, the restructuring of the coffee chain suggests (in line with Gibbon, 2001a) that different typologies of "buyers" need to be identified within the buyerdriven category. This is because lead actors who are in different positions in the chain may apply different forms of coordination. Forms of coordination, however, should not be confused with "levels of drivenness," which refer to the degree of power of lead actors in setting modalities and thresholds of inclusion and exclusion. Levels of drivenness tend to be higher in chains led by supermarket chains (fresh fruit and vegetables), ${ }^{27}$ retailers and branded marketers (apparel, footwear), ${ }^{28}$ and industrial processors (coffee, cocoa/chocolate) ${ }^{29}$ than in those led by international traders (cotton, fish, cashew nuts). ${ }^{30}$ They can also change in time, as the coffee study shows. Yet, forms of coordination may be different within highly driven chains, even in the agricultural sector alone. Strategies centered around blending and branding characterize the modalities of chain coordination by roasters in the coffee industry. On the contrary, the fresh fruit and vegetables chain is organized along a system of preferred suppliers that need to match the phytosanitary, process, timing and product quality standards required by supermarket chains (Dolan \& Humphrey, 2000). Standards also play a key role in the rubber chain, which is, however, coordinated by industrial end-users (Daviron, 2002). Vertical integration seems to be the dominant form of coordination in the banana chain (and to some extent in tea and sugar), where global branders who are also producers play a key role (see Gibbon, 2001a, p. 350). In order to be able to offer proper policy and strategic advice to developing countries in selecting involvement (or upgrading) in one chain or another, future GCC research should further analyze the significance of different modes of coordination and the relationship between these and levels of drivenness. It should also examine more systematically the role played by standards, quality conventions and regulation.

\section{CONCLUSIONS AND POLICY OPTIONS}

The GCC approach provides useful tools for the analysis of commodity markets. It examines how key agents build, co-ordinate and control the linkages and flow of produce between producers and consumers, and the roles played in this process by contractual forms, the coordination of finance and business services, and - increasingly - the wider regulatory framework. It pays attention to the organizational aspects of the chain, to the whole range of activities from primary production to final consumption, and to the linkages binding them. GCC analysis also pursues the implications of economic power - in the form of strategic behavior affecting up- and down-stream activities and agents. These aspects are almost entirely ignored in other approaches to the study of commodity trade. ${ }^{31}$

GCC studies have been able to indicate trends in commodity markets that were previously unknown. They have shown that "buyers" of various kinds (supermarket chains, processors and international traders) are increasingly dominating several commodity chains. GCC studies have also highlighted that these buyers use a variety of mechanisms of chain coordination - such as determination or control of standards and quality conventions, control of market and consumer information, vertical integration, and branding. Furthermore, they 
have underlined that the end of commodity agreements and market liberalization-with the consequent weakening of domestic regulatory powers, including quality control and stock management-have contributed to transferring power from producers (based in developing countries) to consumers (based in industrialized countries). Finally, GCC studies have suggested that policy advice should be based on the specificity of individual commodity chains rather than on the application of a general economic model. ${ }^{32}$

As concerns the coffee industry, this article suggests that the present crisis faced by farmers and producing countries is not only one of overproduction, but also one relating to changes in the governance structure and the institutional framework of the chain. In the global coffee chain, the institutional framework has moved away from a formal and relatively stable system where producers had an established "voice" toward one that is more informal and buyer dominated. In the process, a substantial proportion of total income generated in the coffee chain has been transferred from farmers to consuming country operators. Furthermore, if roasters had provided stability to the ICA regime in their search for an optimum expansion of activities, they are now one of the destabilizing forces in the coffee market. Increased corporate financialization of giant roasting firms entails that their more pressing goal is not expansion of activity per se anymore. ${ }^{33}$ Their goal is rather the maximization of profits in the short term to increase the value of shares, even if it means disposing of noncore functions. In this system, inherent instability is not a major problem for equity holders of roasting firms as investment fund managers can diversify risk for them. International traders, themselves increasingly falling under the same corporate model and its pressures, have either upgraded their functional roles and invested in new logistics systems, restructured their organization, and become more involved in producing countries, or have disappeared. Those trading firms that have survived are hedging increased risk through futures market operations. Local actors in producing countries do not have the same ease of access to hedging instruments. Therefore, they have either allied themselves with international traders or have disappeared. In most cases, they are losing control of processing, domestic trade and export functions. Further consolidation seems inevitable throughout the industry. Smallholder farmers, however, do not have easy "consolidation" options. Their cooperatives find it difficult to compete with local subsidiaries of international trading firms. As governments retreat from the regulation of domestic coffee markets, farmer organizations lose a political forum of negotiation. The weakness and inherent instability of the institutional framework falls straight on the shoulders of coffee farmers in developing countries. The policy and strategic advice that follows is based on these observations.

Coffee-producing countries are slowly realizing that the revival of the ICA system with quotas and price bands does not seem to be possible in the short term. There is no public or political support for quotas in consuming countries nor-with the end of the Cold War-is there a foreign policy reason for it. Retention schemes through producer cartels, such as the recent effort organized by the ACPC, have not been able to influence markets in the presence of a fundamental excess of supply. A second option that has been proposed in the coffee sector is the establishment of quotas on production. This could be, in theory, a better solution but is opposite to what governments have been promoting in the past in their own countries, that is higher-not lower-production. A third and more promising option, at least in the short term, is the withdrawal of low-quality coffee beans from the international market. This option has been discussed within the ICO and has found some support from consuming country governments. An ICO Quality Committee is presently discussing a minimum coffee quality standard for export. The basic idea is to reduce supply in the short term and raise the overall quality, therefore value, of coffee exports.

Whether the ICO "quality initiative" succeeds or not, donors and producing country governments should also increase their efforts in promoting "conscious consumption" for it can provide an extra channel for small producers in recapturing a higher proportion of the total income generated in the coffee chain. One way is through increased promotion of fair trade. Fair trade operators pay a minimum floor price to registered producer organizations and cooperatives. They also offer financial and technical support. The relative success of fair trade in Europe in the 1990s has shown that some consumers are willing to pay a premium for coffee so that farmers receive a just payment for their effort. Other forms of conscious consumption are consumption of organic, shade- 
grown and bird-friendly coffees. The transition to organic farming is relatively easy in Robusta coffee cultivation, especially in Africa where chemical input use is low. Many producers are already growing organic coffee, but are being paid prices for nonorganic coffee. They lack information on certification processes and on how to approach certification agencies. The development of sun-resistant large-scale coffee plantations has led to the uprooting of trees and loss of biodiversity - except where coffee is cultivated in areas of natural savannah. These trees used to provide shade to coffee bushes and a natural habitat for birds in more "traditional" coffee farming systems. Again, smallholders cultivate coffee under shade trees already, but consumers are not paying a premium for it.

While the markets for "conscious" coffees are growing and constitute an important development channel, they are likely to remain niche markets in the near future. In addition, the ICO idea of a ban on exports of low-quality coffee is unlikely to be supported by consuming country governments in the long term. Therefore, solving the current imbalances in the global coffee chain also requires initiatives aimed at improving coffee quality in producing countries and the appreciation of quality in consuming countries. Producing countries need to raise the reputation of individual origins and refine marketing skills. The key for would-be producers of high-quality coffees is to know how to sell the right coffee to the right people. They need to know which quality characteristics are appreciated where, what kind of premium will be paid, and what are the motivations that are needed for consumers to take a product seriously. Selling a "story" is particularly important. Farmer groups and/or co-operatives could be helped to become better at exploiting their stories than they are doing now. Market failures in agricultural input and credit markets should also be tackled because they are making it difficult for producers to improve quality (see also Ponte, 2001, 2002c). Furthermore, new initiatives should be aimed at "cultivating" consumers rather than more coffee. A consumer who knows how to discern the intrinsic qualities of coffee will look for particular kinds of coffee and be willing to pay more for its specificity. More informed consumers are also a market-based guarantee for higher demand of better quality coffee. Finally, they can address power imbalances in the global coffee chain by facilitating market fragmentation. ${ }^{34}$

Even if the "latte revolution" and initiatives aimed at "cultivating" consumers worked in permanently fragmenting and upgrading coffee consumption, the developmental impact in producing countries will not appear unless donors, the ICO, NGOs and producing country governments ensure that value added is transferred to producers. This can be done by (a) facilitating the establishment of farmer groups and producer associations and of direct links between them and consumers; (b) promoting regulation requiring coffee buyers in producing countries to pay producers higher prices for higher quality coffee; and (c) developing systems of appellation similar to the ones used in the wine industry.

\section{NOTES}

1. Fitter and Kaplinsky (2001, p. 76) estimate that the coffee content of the cost of a cappuccino bought in a coffee bar in the UK is less than $4 \%$.

2. This term was first used in Dicum and Luttinger (1999).

3. Gereffi himself has mainly applied the GCC framework to analyzing exports of apparel from East Asian countries, Mexico and the Caribbean to the United States (Appelbaum \& Gereffi, 1994; Gereffi, 1994, 1999a), exports of footwear (Gereffi \& Korzeniewicz, 1990) and e-commerce (Gereffi, 2001a,b). Other GCC and related studies have analyzed: services (Clancy, 1998; Pedersen, 2000; Rabach \& Kim, 1994); footwear (Schmitz, 1999); electronics and semiconductors (Borrus, 1994; Henderson, 1989; Humphrey, 2000; Lee \&
Cason, 1994; Kenney \& Florida, 1994); furniture (Kaplinsky \& Readman, 2000); automobiles and auto components (Barnes \& Kaplinsky, 1999; Doner, 1991; Hill, 1989; Kaplinsky \& Morris, 1999; Sturgeon, 1999, 2001), illicit commodities (Wilson \& Zambrano, 1994), and apparel/garments (Bonacich, Cheng, Chinchilla, Hamilton, \& Ong, 1994; Gibbon, 2000, 2001b; Kessler, 1999).

4. See, among others, Gibbon (1999) and Larsen (2001, 2002) on cotton; Raikes and Gibbon (2000) on African export crops; Gibbon (1997) on fish; Kaplan and Kaplinsky (1999) on fruit canning; Barrett, Ilbery, Browne, and Binns (1999), Calvin and Barrios (2000), Dolan, Humphrey, and Harris-Pascal (1999), Dolan and Humphrey (2000) and Raynolds (1994) on fresh fruit 
and/or vegetables; Fitter and Kaplinsky (2001), Ponte (2002a) and Talbot (1997a,b) on coffee; and Fold (2001, 2002) on cocoa.

5. For exceptions to this rule, see Gibbon (2001a) and Raikes and Gibbon (2000).

6. The major exception is Brazil, which is the top producer and also one of the main consuming countries in the world.

7. This has changed recently. In 1996-97, coffee ranked only fifth among internationally traded commodities after oil, aluminum, wheat and coal.

8. In Africa, for example, coffee exports in 1996-98 represented more than $50 \%$ of agricultural export earnings in five countries, and more than $20 \%$ in nine countries. In three of these countries, coffee exports represented more than $50 \%$ of total merchandise exports, and in eight countries more than $10 \%$ (see Ponte, 2002a).

9. The ICO classification does not take into consideration that some countries produce different types of coffee: Brazil, for example, produces Robusta as well as Hard Arabica. Cameroon, India, Papua New Guinea, Tanzania and Uganda also produce both Robusta and Arabica. These countries are classified in accordance to the main type of coffee they produce.

10. Coffee is also traded in its instant and roasted forms. Trade between producing and consuming countries consists mostly of green coffee and bulk instant coffee. Bulk instant coffee imported from producing countries is usually blended and re-packaged in consuming countries. The roasted coffee trade takes place almost exclusively between consuming countries. This pattern of trade comes from the fact that green and instant coffees can be stored for a long period of time, while roasted coffee loses its freshness much more quickly.

11. Currently, the ACPC has 14 ratified members: Angola, Brazil, Colombia, Costa Rica, Côte d'Ivoire, DR Congo, El Salvador, India, Indonesia, Kenya, Tanzania, Togo, Uganda and Venezuela. Together, they make up nearly $85 \%$ of world coffee supply.

12. Vietnam (No. 2 world producer, ranked by volume of 1999-2000 crop), Mexico (No. 4), and Guatemala (No. 8).

13. Coffee stocks in the United States have risen from 2.7 million bags in May 1999 to over five million bags in January 2001. May 2000 was the first time since 1994 that stocks topped five million bags.
14. Calculated from CSCE (2001) data. Fitter and Kaplinsky (2001, p. 77) show a similar trend using a different data set.

15. Talbot (1997a, p. 63) defines the total income generated along the coffee chain as "equal to the total amount of money spent by consumers to purchase coffee products for final consumption."

16. The remaining shares of total coffee income are (a) transport costs and weight losses; and (b) value added in producing countries.

17. Talbot's (1997a) calculations are based on weighted average prices for all ICO member countries at various nodes of the chain. An alternative approach is to calculate the distribution of value along specific producer-consumer country chains. Pelupessy (1999) has applied this method to the Côte d'Ivoire-France and the Costa Rica-Germany chains. The results are fairly similar to Talbot's. In 1994, the grower's share of total retail price was $13.8 \%$ in Côte d'Ivoire and $14.6 \%$ in Costa Rica.

18. Producer-held stocks were estimated at $21.2 \mathrm{~m}$ bags in 2000-01 (Prudential Securities Futures Research: Coffee, June 28, 2000).

19. Recent takeover instances include Rothfos by Neumann, SICAFE by Bolloré, and ACLII by Cargill (Daviron, 1996). In 2000, Cargill sold its coffee interests to ECOM.

20. Exceptions are represented by Decotrade, the trading arm of Sara Lee/Douwe Egberts, and Taloca, which is owned by the Jacobs Suchard/Kraft group (Philip Morris). Tchibo has a trading arm that is very active in Kenya and Tanzania. Roasters/traders, however, do not rely on their trading arms alone for their supply needs. They source from a variety of other international traders as well.

21. Roasters producing high-quality blends need to have greater cover (store a larger number of varieties and origins) than roasters that produce "traditional" blends. The latter are able to substitute coffee types more readily than the former.

22. "Upstream" means movement toward producers. "Downstream" means movement toward consumers.

23. Vertical integration issues are more complex in the case of instant coffee, where a number of manufacturers have installed plants in coffee-producing countries. For 
an exhaustive treatment of this subsector of the coffee industry, see Talbot (1997b).

24. By "conscious" consumption, I mean consumption of fair trade, organic, shade-grown and bird-friendly coffees.

25. Maxwell House was bought by General Foods back in 1928. Folgers was taken over by Procter \& Gamble in 1963. General Foods was eventually taken over by Philip Morris in 1985 and merged with Kraft in 1995.

26. Similarly, Dolan and Humphrey (2000) emphasized how the UK 1990 Food Safety Act has influenced the governance structure of the fresh fruit and vegetables chain and the possibilities and modalities of upgrading. The Act requires retailers to be able to trace their products all the way to the farm level.

27. See Dolan et al. (1999) and Dolan and Humphrey (2000).

28. See Gereffi (1994, 1999a) and Gibbon (2000).

29. It is not completely clear to what extent the cocoa/ chocolate chain fits other buyer-driven commodity chains. Fold (2002) characterizes its mode of governance as "bi-polar," where the two lead actors are cocoa grinders and chocolate branders.

30. See Cramer (1999) and Gibbon (2001a).
31. A notable exception is the French filiere approach, which is a loosely knit set of studies with the common characteristic that they use the filiere (or chain) of activities and exchanges as a tool and to delimit the scope of their analysis. This approach is seen by most of its practitioners as a neutral, practical tool of analysis for use in "down-to-earth" applied research (see Raikes et al., 2000). Another exception is business economics, where the notion of chains of activities linked by complex networks of contracts and subcontracts is widely accepted. Porter's (1990) "value chains" are somewhat similar to GCCs, and the concept of supply chain management has become increasingly important in recent years. There is also some convergence with Whitley's (1992, 1999) notion of business systems, although Whitley (1996) is critical of several aspects of the GCC approach.

32. For example, the experience of African agricultural commodity trade suggests that improved market efficiency is beneficial to farmers and producer countries only when their main "insertion" point in a GCC is volume rather than quality. Therefore, market liberalization may be the best option for some countries, while highly regulated markets may be the best for otherseven within the framework of the same commodity (see Friis-Hansen, 2000; Ponte, 2002a).

33. On corporate financialization, see Grahl (2001) and Froud, Haslam, Johal, and Williams (2000).

34. For more details on specific policy options, see Ponte (2002b).

\section{REFERENCES}

Akiyama, T. (2001). Coffee market liberalization since 1990. In T. Akiyama, J. Baffes, D. F. Larson, \& P. Varangis (Eds.), Commodity market reforms: lessons of two decades. Washington, DC: World Bank.

Akiyama, T., \& Varangis, P. (1990). The impact of the international coffee agreement on producing countries. World Bank Economic Review, 4(2), 157-173.

Appelbaum, R. P., \& Gereffi, G. (1994). Power and profits in the apparel commodity chain. In E. Bonacich, L. Cheng, N. Chinchilla, N. Hamilton, \& P. Ong (Eds.), Global production: the apparel industry in the Pacific Rim. Philadelphia: Temple University Press.

Barnes, J., \& Kaplinsky, R. (1999). Globalization and trade policy reform: whither the automobile components sector in South Africa. Mimeo, Institute of Development Studies, University of Sussex, Brighton.

Barrett, H. R., Ilbery, B. W., Browne, A. W., \& Binns, T. (1999). Globalization and the changing networks of food supply: the importation of fresh horticultural produce from Kenya into the UK. Transactions of the Institute of British Geographers, 24, 159-174.

Bates, R. H. (1997). Open-economy politics: the political economy of the world coffee trade. Princeton: Princeton University Press.

Bonacich, E., Cheng, L., Chinchilla, N., Hamilton, N., \& Ong, P. (Eds.). (1994). Global production: the apparel industry in the Pacific Rim. Philadelphia: Temple University Press.

Borrus, M. (1994). Left for dead: Asian production networks and the revival of U.S. electronics. In E. M. Doherty (Ed.), Japanese investment in Asia: international production strategies in a rapidly changing world. San Francisco: The Asia Foundation and the University of California at Berkeley.

Calvin, L., \& Barrios, V. (2000). Marketing winter vegetables from Mexico. Paper presented at the IDS/ Rockefeller Foundation Meeting on Global Value Chains, Bellagio, Italy, September 25-October 2. 
Clancy, M. (1998). Commodity chains, services and development: theory and preliminary evidence from the tourism industry. Review of International Political Economy, 5(1), 122-148.

Coffee, Sugar and Cocoa Exchange-New York (CSCE) (2001). Available: http://www.csce.com.

Cramer, C. (1999). Can Africa industrialize by processing primary commodities? The case of Mozambican cashew nuts. World Development, 27(7), 1247-1266.

Crowe, T. (1997). Coffee futures price behavior and fund investment. ICO Coffee Newsletter, 4.

Daviron, B. (1993). Conflict et Cooperation sur le Marché International du Café: Une Analyse de Longue Periode. Thèse de Doctorat, Ecole Nationale Supérieure Agronomique de Montpellier, Montpellier.

Daviron, B. (1996). The rise and fall of governmental power on the international coffee market. In M. Griffon, \& P. Guillaumont (Eds.), Economics of agricultural policies in developing countries. Paris: Editions de la Revue Française d'Economie.

Daviron, B. (2002). Small farm production and the standardization of tropical products. Journal of Agrarian Change, 2(2), 137-161.

Dicum, G., \& Luttinger, N. (1999). The coffee book: anatomy of an industry from the crop to the last drop. New York: The New Press.

Dolan, C., Humphrey, J., \& Harris-Pascal, C. (1999). Horticulture commodity chains: the impact of the UK market on the African fresh vegetable Industry. Mimeo, Institute of Development Studies, University of Sussex, Brighton.

Dolan, C., \& Humphrey, J. (2000). Governance and trade in fresh vegetables: the impact of UK supermarkets on the African horticulture industry. Journal of Development Studies, 37(2), 147-176.

Doner, R. F. (1991). Driving a bargain: automobile industrialization and Japanese firms in Southeast Asia. Berkeley: University of California Press.

Financial Times, London, April 27, 2001.

Fitter, R., \& Kaplinsky, R. (2001). Who gains from product rents as the coffee market becomes more differentiated? A value-chain analysis. IDS Bulletin, 32(3), 69-82.

Fold, N. (2001). Restructuring of the European chocolate industry and its impact on cocoa production in West Africa. Journal of Economic Geography, 1(3), 405-420.

Fold, N. (2002). Lead firms and competition in 'bi-polar' commodity chains: grinders and branders in the global cocoa-chocolate industry. Journal of Agrarian Change, 2(2), 228-247.

Friis-Hansen, E. (Ed.). (2000). CDR Policy Paper Series, Agricultural policy in Africa after adjustment. Copenhagen: Centre for Development Research.

Froud, J., Haslam, C., Johal, S., \& Williams, K. (Eds.). (2000). Shareholder value and the political economy of late capitalism [Special issue]. Economy and Society, 29(1).

Gereffi, G. (1994). The organization of buyer-driven global commodity chains: how US retailers shape overseas production networks. In G. Gereffi, \& M.
Korzeniewicz (Eds.), Commodity chains and global capitalism. Westport: Greenwood Press.

Gereffi, G. (1995). Global production systems and Third World development. In B. Stallings (Ed.), Global change, regional response: the new international context of development. Cambridge: Cambridge University Press.

Gereffi, G. (1999a). International trade and industrial up-grading in the apparel commodity chain. Journal of International Economics, 48(1), 37-70.

Gereffi, G. (1999b). A commodity chains framework for analyzing global industries. Mimeo, Department of Sociology, Duke University, Durham.

Gereffi, G. (2001a). Beyond the producer-driven/buyerdriven dichotomy. The evolution of global value chains in the internet era. IDS Bulletin, 32(3), 30-40.

Gereffi, G. (2001b). Shifting governance structures in global commodity chains, with special reference to the internet. American Behavioral Scientist, 44(10), 1616-1637.

Gereffi, G., \& Korzeniewicz, M. (1990). Commodity chains and footwear exports in the semiperiphery. In W. G. Martin (Ed.), Semiperipheral states in the world economy. Westport: Greenwood Press.

Gereffi, G., Korzeniewicz, K., \& Korzeniewicz, R. (1994). Introduction: global commodity chains. In G. Gereffi, \& M. Korzeniewicz (Eds.), Commodity chains and global capitalism. Westport: Greenwood Press.

Gibbon, P. (1997). Of saviours and punks: the political economy of the Nile perch marketing chain in Tanzania. CDR Working Papers 97.3, Centre for Development Research, Copenhagen.

Gibbon, P. (1999). Free competition without sustainable development? Tanzanian cotton sector liberalization 1994/95-1997/98. Journal of Development Studies, $36(1), 128-150$.

Gibbon, P. (2000). "Back to the basics" through delocalisation: the Mauritian garment industry at the end of the twentieth century. CDR Working Papers 00.7, Centre for Development Research, Copenhagen.

Gibbon, P. (2001a). Upgrading primary production: a global commodity chain approach. World Development, 29(2), 345-363.

Gibbon, P. (2001b). At the cutting edge: UK clothing retailers and global sourcing. CDR Working Papers 01.4, Centre for Development Research, Copenhagen.

Gilbert, C. L. (1996). International commodity agreements: an obituary. World Development, 24(1), 1-19.

Gilbert, C. L. (1998). What kind of economic clauses could generally be acceptable in a new international coffee agreement? ICO Coffee Newsletter, 7.

Grahl, J. (2001). Globalized finance: the challenge to the Euro. New Left Review, 8, 23-47.

Henderson, J. (1989). The globalization of high technology production: society, space and semiconductors in the restructuring of the modern world. London and New York: Routledge.

Hill, R. C. (1989). Comparing transnational production systems: the automobile industry in the USA and 
Japan. International Journal of Urban and Regional Research, 13(3), 462-480.

Hopkins, T. K., \& Wallerstein, I. (1986). Commodity chains in the world economy prior to 1800 . Review, 10(1), 157-170.

Humphrey, J. (2000). Globalization and supply chain networks: the auto industry in Brazil and India. Paper presented at the IDS/Rockefeller Foundation Meeting on Global Value Chains, Bellagio, Italy, September 25-October 2.

Humphrey, J., \& Schmitz, H. (2000). Governance and upgrading in global value chains. Paper presented at the IDS/Rockefeller Foundation Meeting on Global Value Chains, Bellagio, Italy, September 25-October 2 .

International Coffee Organization (ICO), International Trade Centre UNCTAD/WTO (ITC), \& Common Fund for Commodities (CFC) (2000). The government coffee project: adding value to green coffee (2 volumes). London, Geneva and Amsterdam: ICO, ITC and CFC.

International Coffee Organization (ICO) (2001a). Available: http://www.ico.org/asp/statschoice2.htm.

International Coffee Organization (ICO) (2001b). Available: http://www.ico.org/statist/po2.htm.

Kaplan, D., \& Kaplinsky, R. (1999). Trade and industrial policy on an uneven playing field: the case of the deciduous fruit canning industry in South Africa. World Development, 27(10), 1787-1801.

Kaplinsky, R., \& Morris, M. (1999). Trade policy reform and the competitive response in Kwazulu Natal Province, South Africa. World Development, 27(4), 717-737.

Kaplinsky, R., \& Readman, J. (2000). Globalization and upgrading: what can (and cannot) be learnt from international trade statistics in the wood furniture sector. Paper presented at the IDS/Rockefeller Foundation Meeting on Global Value Chains, Bellagio, Italy, September 25-October 2.

Kenney, M., \& Florida, R. (1994). Japanese maquiladoras: production organization and global commodity chains. World Development, 22(1), 27-44.

Kessler, J. A. (1999). The North American Free Trade Agreement, emerging apparel production networks and industrial upgrading: the Southern California/ Mexico connection. Review of International Political Economy, 6(4), 565-608.

Larsen, M. N. (2001). Zimbabwean cotton sector liberalization: a case of successful private coordination? CDR Working Papers 01.1, Centre for Development Research, Copenhagen.

Larsen, M. N. (2002). Is oligopoly a condition of successful privatization? The case of cotton in Zimbabwe. Journal of Agrarian Change, 2(2), 185205.

Lee, N., \& Cason, J. (1994). Automobile commodity chains in the NICs: a comparison of South Korea, Mexico and Brazil. In G. Gereffi, \& M. Korzeniewicz (Eds.), Commodity chains and global capitalism. Westport: Greenwood Press.

Lodder, C. A. (1997). The just-in-time policy: some conditions for success. ICO Coffee Newsletter, 5.
Losch, B. (1999). Le complexe café-cacao de la Côte d'Ivoire (two volumes). Thèse de Doctorat. Université Montpellier I, Montpellier.

Lucier, R. L. (1988). The international political economy of coffee: from Juan Valdez to Yank's diner. New York and London: Praeger.

McClumpha, A. D. (1988). The trading of green coffee. In R. J. Clarke, \& R. Macrae (Eds.), Coffee (volume 6): commercial and technico-legal aspects. London and New York: Elsevier Applied Science.

Palm, F. C., \& Vogelvang, B. (1991). The effectiveness of the world coffee agreement: a simulation study using a quarterly model of the world coffee market. In O. Guvenen, W. C. Labys, \& J. B. Lesourd (Eds.), International commodity market models. London: Chapman and Hall.

Pedersen, P. O. (2000). The changing structure of transport under trade liberalization and globalization and its impact on African rural development. CDR Working Papers 00.1, Centre for Development Research, Copenhagen.

Pelupessy, W. (1999). Coffee in Cote d'Ivoire and Costa Rica: national and global aspects of competitiveness. In H. L. van der Laan, T. Dijkstra, \& A. van Tilburg (Eds.), Leiden, African Studies Centre Research Series 15/1999, Agricultural marketing in tropical Africa: contributions from the Netherlands. Ashgate: Aldershot.

Pendergrast, M. (2001). Uncommon grounds: the history of coffee and how it transformed our world. New York: Basic Books.

Ponte, S. (2001). Policy reforms, market failures and input use in african smallholder agriculture. European Journal of Development Research, 13(1), 1-29.

Ponte, S. (2002a). Brewing a bitter cup? Deregulation, quality and the re-organization of the coffee marketing chain in East Africa. Journal of Agrarian Change, 2(2), 248-272.

Ponte, S. (2002b). The 'coffee crisis': quantity vs. quality in production and consumption. CDR Aid Policy and Practice Issue Paper, Centre for Development Research, Copenhagen.

Ponte, S. (2002c). Farmers and markets in Tanzania: how market reforms affect rural livelihoods in Africa. Oxford and Portsmouth: James Currey and Heinemann.

Porter, M. (1990). The competitive advantage of nations. Boston: Harvard Business School Press.

Prudential Securities Futures Research-Coffee, New York, June 28, 2000.

Rabach, E., \& Kim, E. M. (1994). Where is the chain in commodity chains? The service sector nexus. In G. Gereffi, \& M. Korzeniewicz (Eds.), Commodity chains and global capitalism. Westport: Greenwood Press.

Raikes, P., \& Gibbon, P. (2000). "Globalization" and African export crop agriculture. Journal of Peasant Studies, 27(2), 50-93.

Raikes, P., Jensen, M. F., \& Ponte, S. (2000). Global commodity chain analysis and the French filiere approach: comparison and critique. Economy and Society, 29(3), 390-417. 
Raynolds, L. T. (1994). Institutionalizing flexibility: a comparative analysis of fordist and post-fordist models of Third World agro-export production. In G. Gereffi, \& M. Korzeniewicz (Eds.), Commodity chains and global capitalism. Westport: Greenwood Press.

Schmitz, H. (1999). Global competition and local cooperation: success and failures in the Sinos Valley, Brazil. World Development, 27(9), 1627-1650.

Starbucks (2001). Available: http://www.starbucks.com.

Sturgeon, T. J. (1999). Turn-key production networks: industry organization, economic development, and the globalization of electronics contract manufacturing. Ph.D. dissertation. Department of Geography, University of California at Berkeley, Berkeley.

Sturgeon, T. J. (2001). How do we define value chains and production networks? IDS Bulletin, 32(3), 9-18.

Talbot, J. M. (1997a). Where does your coffee dollar go? The division of income and surplus along the coffee commodity chain. Studies in Comparative International Development, 32(1), 56-91.

Talbot, J. M. (1997b). The struggle for control of a commodity chain: instant coffee from Latin America.
Latin American Research Review, 32(2), 117135.

Tam, T., \& Gereffi, G. (1999). Industrial upgrading and organizational chains. Mimeo, Department of Sociology, Duke University, Durham.

van Dijk, J. B., van Doesburg, D. H. M., Heijbroek, A. M. A., Wazir, M. R. I. A., \& de Wolff, G. S. M. (1998). The world coffee market. Utrecht: Rabobank International.

Whitley, R. (1992). Business systems in East Asia: firms, markets and societies. London: Sage.

Whitley, R. (1996). Business systems and global commodity chains: competing or complementary forms of economic organisation. Competition and Change, $1,411-425$.

Whitley, R. (1999). Divergent capitalisms: the social structuring and change of business systems. New York and Oxford: Oxford University Press.

Wilson, S., \& Zambrano, M. (1994). Cocaine, commodity chains and drug policies: a transnational approach. In G. Gereffi, \& M. Korzeniewicz (Eds.), Commodity chains and global capitalism. Westport: Greenwood Press. 